\title{
Hunting of large mammals and pheasants in the Indian western Himalaya
}

\author{
Rahul Kaul, Hilaluddin, J.S. Jandrotia and Philip J.K. McGowan
}

\begin{abstract}
We conducted a survey in the western Himalaya of India to assess animal extraction patterns. Data on animal species and their extraction patterns, their importance to the respondents, and reasons and methods of hunting were collected using structured questionnaires. Twenty-three species of large mammals and Galliformes were present in the area, 18 of which were hunted around at least one village. Of special concern were several threatened species that were hunted around most villages were they occurred, although the
\end{abstract}

impact of removal on wild populations is not clear. The main reason for hunting was to supplement animal protein, although some animals were also killed for sale of meat and their parts. The establishment of communitymanaged forests has not had an impact on extraction rates. Assessment of the impact of hunting on the threatened species in particular is urgently required.

Keywords Bushmeat, Galliformes, hunting, India, mammals, pheasants, western Himalaya, wildmeat.

\section{Introduction}

Overhunting is considered the second most common cause of recent animal extinctions after habitat destruction (Diamond \& Case, 1986; Reid, 1992) and is similarly considered to lie only behind habitat destruction and degradation in current assessments of pressures likely to lead to future species extinctions (Hilton-Taylor, 2000; BirdLife International, 2004). To date most conservation interest has concentrated on documenting and analysing patterns of extraction of large tropical forest species (Peres \& Terborgh, 1995; Alvard et al., 1997; Bodmer et al., 1997; Wilkie \& Carpenter, 1999; Robinson \& Bennett, 2000; Bakarr et al., 2001). There is little information on extraction levels and patterns in some other terrestrial regions of the world, and such information is increasingly important in those areas where habitat loss is leading to decreasing populations of species that are increasingly fragmented. One such area is the Himalayas, which is of global importance for the conservation of biological diversity (ICBP, 1992; Olson \& Dinerstein, 1998) and that contains many threatened species (IUCN, 2003).

Rahul Kaul (Corresponding author) and Hilaluddin World Pheasan Association, South Asia Field Office, K-5 (First floor), Green Park, New Delhi - 16, India. E-mail rahulkaul101@sify.com

J.S. Jandrotia District Institute of Education and Training, Chamba, Himachal Pradesh, India.

Philip J.K. McGowan World Pheasant Association, 7-9 Shaftesbury Street, Fordingbridge, Hampshire, SP6 1RF, UK.

Received 30 June 2003. Revision requested 24 March 2004. Accepted 3 June 2004
Much of the Himalayas fall within India, which forms $2.4 \%$ of the earth's landmass and supports $16 \%$ of the world's human population (Anon., 2000). Nineteen percent of its landmass is under forest (Anon., 1999), but because of the extremely dense human population $(0.07$ hectare per capita) few areas remain inviolate.

Legally, species are protected from hunting and trade through the Wildlife (Protection) Act, 1972. Nevertheless, hunting in the Himalaya, which has traditionally been for subsistence and/or trade, continues. Although this legislation has apparently succeeded in curbing some open trade of animals and their parts, subsistence hunting continues at an unknown scale. Therefore, we undertook a survey to assess whether the extraction of wildmeat was a conservation problem in part of the western Himalaya. Specifically we sought to determine (1) the prevalence of hunting, the species hunted and the quantity extracted, (2) the reasons why people hunt, and (3) whether hunting pressure varied between community- and state-managed forests.

\section{Study area}

The study was conducted during 2002 in one district of Himachal Pradesh and five districts of the adjacent hill state of Uttaranchal over 1,100-3,000 m altitude. These areas fall within India's biogeographic province 2B Western Himalaya (Rodgers \& Panwar, 1988) and forms part of the Western Himalaya Endemic Bird Area (ICBP, 1992; Stattersfield et al., 1998). Within this area, 21 villages or hamlets were surveyed from the outer, middle and inner Himalayan ranges, thereby covering most forest types occurring in the western Indian Himalaya. 
Eight of these villages were in Himachal Pradesh and 13 in Uttaranchal.

\section{Methods}

Data were collected through Rapid Rural Appraisal structured interviews (Sethi \& Hilaluddin, 2001) with inhabitants of villages, some of whom hunted and some of whom did not. Our sampling was framed within social and cultural constraints inasmuch as it was not always possible to randomly select people for interview because some village groups were busier than others during the study period and because females were shy and reluctant to answer questions.

In each village or hamlet one interview was conducted to obtain general information on the species hunted and the extent of hunting. During these interviews, households that were reportedly engaged in hunting were identified for further interviews. At least $5 \%$ of such households in each village or hamlet were sampled. Seventy-five such household-level interviews (19 in Himachal Pradesh and 56 in Uttaranchal) were conducted in all. However, amongst these, 32\% of respondents did not admit to hunting either because they really did not hunt or they did not wish to talk about this controversial topic. During these second stage interviews we asked which species were hunted, why they were hunted and the number of individual animals killed during the last 12 months.

Species considered to be available for hunting in a particular area were determined by combining information on the distance that hunters travelled and that on species' distributions, including from our own surveys. Species hunted and the reasons for hunting were taken directly from the results of structured interviews. Extraction patterns were analysed at two levels. Firstly, we looked at the spatial distribution of hunting by calculating the percentage of villages around which a species was hunted. Therefore, if a species was hunted around four of the 12 villages from which it was reported, it was hunted in $33 \%$ of villages. Secondly, we calculated the offtake by analysing the number of individuals that hunting households reported they killed each year. Again, not all species were present around all villages and so when a species was not present it was not considered available for a household to hunt. Thus there are different sample sizes in the results. The average extraction of meat by weight was calculated by multiplying the number of animals reportedly killed each year per household by the species' average body weight (Prater, 1971; Ali \& Ripley, 1987).

Comparisons of differences in extraction rates between community-managed and state-managed forest areas was possible only for Uttaranchal, as there are no community-managed forest areas in Himachal Pradesh. Each village was assigned to one category or the other. Differences in harvesting were compared using MannWhitney U tests.

\section{Results}

Only $8-10 \%$ of people in a village hunted, but other villagers shared the meat obtained by them. Hunting was exclusively carried out with guns in Himachal Pradesh, whereas hunters in Uttaranchal used either guns (42\%) or snares $(48 \%)$ only, or both $(10 \%)$.

Twenty-three species of large mammal and Galliformes were found around at least some of the villages that we surveyed; 13 of these were mammals and 10 were pheasants, partridges and quail (Table 1). Of these, five species (quail Perdicula sp., sambar Cerous unicolor, Himalayan langur Presbytis entellus, rhesus macaque Macaca mulata and serow Capricornis sumatrensis) were not hunted at all, and the common hill-partridge only around one village. Seven species were hunted by hunters in at least $60 \%$ of the villages around which they were found, with Himalayan tahr Hemitragus jemlachus, western tragopan Tragopan melanocephalus, musk deer Moschus chrysogaster and Himalayan monal Lophophorus impejanus being most widely hunted. All of these species were overwhelmingly distributed and hunted in Himachal Pradesh; the only hunting of any of these four species in Uttaranchal was that of musk deer around a single village.

The most widely hunted species in Uttaranchal were black francolin Francolinus francolinus, chukar partridge Alectoris chukar, koklass pheasant Pucrasia macrolopha, white-crested kalij Lophura leucomelanos, barking deer Muntiacus muntjak, goral Nemorhaedus goral, Indian porcupine Hystrix indica and Indian wildboar Sus scrofa. In Himachal Pradesh the widely hunted species were cheer pheasant Catreus wallichi, chukar partridge, koklass pheasant, Himalayan monal, western tragopan, barking deer, goral, Himalayan black bear Selenarctos thibetanus, Himalayan brown bear Ursus arctos, Himalayan tahr, musk deer and leopard Panthera pardus.

The number of individuals of each species that were killed by each hunting household during the previous year is given in Table 2. The mean offtake per hunting household was highest for kalij pheasant, chukar partridge and koklass pheasant. More goral were killed than any other mammal. There were differences in offtake patterns among species between the two states. In Uttaranchal, a mean of nine kalij was killed by each hunting household, whereas none were killed in Himachal Pradesh, even though they were present. In contrast, many more individuals of three other Galliformes (cheer pheasant, chukar partridge and 
Table 1 Species of large mammals and Galliformes occurring in the study area, with the number of villages around which each species occurs, and the number and percentage of villages in which the species is hunted; species are ordered from the most to the least hunted.

\begin{tabular}{|c|c|c|c|}
\hline \multirow[b]{2}{*}{ Common name } & \multirow[b]{2}{*}{ Scientific name } & \multicolumn{2}{|l|}{ No. villages } \\
\hline & & Where present & Where hunted (\%) \\
\hline Himalayan $\operatorname{tahr}^{\mathrm{V}}$ & Hemitragus jemlahicus & 8 & $7(88)$ \\
\hline Western tragopan ${ }^{\mathrm{V}}$ & Tragopan melanocephalus & 6 & $5(83)$ \\
\hline Musk deer ${ }^{\mathrm{L}}$ & Moschus chrysogaster & 9 & $7(78)$ \\
\hline Himalayan monal & Lophophorus impejanus & 8 & $6(75)$ \\
\hline Cheer pheasant $^{\mathrm{V}}$ & Catreus wallichi & 12 & $8(67)$ \\
\hline Goral $^{\mathrm{L}}$ & Nemorhaedus goral & 21 & $14(67)$ \\
\hline Koklass pheasant & Pucrasia macrolopha & 20 & $13(65)$ \\
\hline Chukar partridge & Alectoris chukar & 17 & $10(59)$ \\
\hline White-crested kalij & Lophura leucomelanos & 21 & $12(57)$ \\
\hline Barking deer & Muntiacus muntjak & 20 & $10(50)$ \\
\hline Himalayan brown bear & Ursus arctos & 9 & $4(44)$ \\
\hline Indian wildboar & Sus scrofa & 18 & $5(28)$ \\
\hline Himalayan snowcock & Tetroaogallus himalayensis & 8 & $2(25)$ \\
\hline Leopard & Panthera pardus & 20 & $5(25)$ \\
\hline Himalayan black bear ${ }^{\mathrm{V}}$ & Ursus thibetanus & 21 & $5(24)$ \\
\hline Black francolin & Francolinus francolinus & 19 & $4(21)$ \\
\hline Indian porcupine & Hystrix indica & 20 & $3(15)$ \\
\hline Common hill-partridge & Arborophila torqueola & 21 & $1(5)$ \\
\hline Quail & Perdicula sp. & 14 & $0(0)$ \\
\hline Sambar & Cerous unicolor & 7 & $0(0)$ \\
\hline Himalayan langur & Presbytis entellus & 11 & $0(0)$ \\
\hline Rhesus macaque & Macaca mulata & 8 & $0(0)$ \\
\hline Serow $^{v}$ & Capricornis sumatraensis & 2 & $0(0)$ \\
\hline
\end{tabular}

V,LSpecies categorized as Vulnerable and Lower Risk:near-threatened, respectively, on the 2003 IUCN Red List (IUCN, 2003).

Table 2 Extraction of Galliformes and mammals in the western Indian Himalaya, with Mann-Whitney test for differences between Himachal Pradesh and Uttaranchal (only for those with non-zero values). Numbers in parentheses are sample sizes (number of hunting households); as not all species were available to all hunting households, sample sizes vary.

\begin{tabular}{|c|c|c|c|c|c|}
\hline \multirow[b]{2}{*}{ Species } & \multicolumn{3}{|c|}{ Number of animals per household per year $($ mean \pm S.E. $(\mathrm{N})$ ) } & \multicolumn{2}{|c|}{ Mann-Whitney } \\
\hline & Himachal & Uttaranchal & Overall & $\mathrm{Z}$ & $\mathrm{P}$ \\
\hline \multicolumn{6}{|l|}{ Galliformes } \\
\hline Black francolin & $0.0(0)$ & $1.28 \pm 0.45$ & $1.28 \pm 0.45$ & & \\
\hline Cheer pheasant & $3.12 \pm 0.84(17)$ & $0.17 \pm 0.16(12)$ & $1.9 \pm 0.56(29)$ & -3.46 & $<0.01$ \\
\hline Chukar partridge & $8.77 \pm 2.13(17)$ & $1.31 \pm 0.63(26)$ & $4.26 \pm 0.99(43)$ & -4.52 & $<0.001$ \\
\hline Common hill-partridge & $0.0(\overline{17})$ & $0.19 \pm 0.1$ & $0.12 \pm 0.11(50)$ & -0.73 & $>0.05$ \\
\hline Himalayan monal & $1.63 \pm 0.39(17)$ & $0.0(5)$ & $1.26 \pm 0.3(22)$ & -3.46 & $<0.01$ \\
\hline Koklass pheasant & $7.96 \pm 1.94(17)$ & $0.55 \pm 0.23(31)$ & $3.17 \pm 0.86(48)$ & -5.3 & $<0.001$ \\
\hline Snowcock & $0.12 \pm 0.1(17)$ & $0.0(3)$ & $0.1 \pm 0.09(20)$ & 0.62 & $>0.05$ \\
\hline Western tragopan & $1.02 \pm 0.21(17)$ & $0.0(0)$ & $1.02 \pm 0.21$ & & \\
\hline White-crested kalij & $0.0(17)$ & $9.0 \pm 1.17(33)$ & $5.94 \pm 0.99(50)$ & -5.26 & $<0.001$ \\
\hline \multicolumn{6}{|l|}{ Mammals } \\
\hline Barking deer & $0.62 \pm 0.12(17)$ & $0.48 \pm 0.18$ & $0.53 \pm 0.13(50)$ & -2.67 & $<0.01$ \\
\hline Goral & $1.71 \pm 0.41(17)$ & $0.7 \pm 0.22$ & $1.04 \pm 0.24(50)$ & -3.4 & $<0.01$ \\
\hline Himalayan black bear & $0.94 \pm 0.21(17)$ & $0.0(33)$ & $0.32 \pm 0.09(50)$ & -5.98 & $<0.001$ \\
\hline Himalayan brown bear & $0.15 \pm 0.08(17)$ & $0.0(3)$ & $0.13 \pm 0.07(20)$ & -1.04 & $>0.05$ \\
\hline Himalayan tahr & $1.21 \pm 0.21(17)$ & $0.0(4)$ & $0.69 \pm 0.23(21)$ & -2.94 & $>0.01$ \\
\hline Indian porcupine & $0.0(\overline{17})$ & $0.34 \pm 0.17(33)$ & $0.22 \pm 0.11(50)$ & -1.5 & $>0.05$ \\
\hline Indian wildboar & $0.0(17)$ & $0.78 \pm 0.25$ & $0.45 \pm 0.16(40)$ & -2.67 & $>0.05$ \\
\hline Leopard & $0.2 \pm 0.08(17)$ & $0.0(33)$ & $0.07 \pm 0.01(50)$ & -4.18 & $<0.001$ \\
\hline Musk deer & $0.56 \pm 0.18$ & $0.75 \pm 0.43(4)$ & $0.6 \pm 0.19$ & -1.06 & $>0.05$ \\
\hline
\end{tabular}


koklass pheasant) were hunted in Himachal Pradesh than in Uttaranchal. The mean number of hunted individuals was less than one for all mammal species, apart from Himalayan tahr and goral in Himachal Pradesh.

Hunting was rarely considered a full-time profession, with most practitioners hunting in their spare time. We identified three main types of hunting activities: (1) organized hunting that targeted large-bodied species or those with a specific market, (2) opportunistic hunting trips into the forest, mainly for subsistence requirements, and (3) routine snaring close to the villages, usually of Galliformes, and primarily to provide meat for the family. If large-bodied quarry were killed, the animals were sometimes sold for cash. Some opportunistic hunting was carried out when winter snow drove animals down to lower altitudes and thus closer to villages.

In addition, animals were occasionally killed for cultural reasons, such as a desire to provide wildmeat to entertain important village guests. More than a quarter of respondents said that they hunted because they had nothing better to do and hunting provided meat or money. For example, many young people depended on part-time jobs (such as labouring, portering and guiding), and when not employed they often hunt.

Two species were hunted for specific body parts: the musk deer for its musk and Himalayan black bear for its gall bladder. In certain areas of Himachal Pradesh, Himalayan tahr was killed for meat and was on sale locally at a lower price than mutton. Monal and western tragopan were also hunted for the sale of their meat in Himachal Pradesh. Indian wildboar was killed because it damaged crops, and leopard because of attacks on cattle.

Wildmeat was the only source of animal protein for $11 \%$ of hunting respondents, whereas for $46 \%$ it supplemented other animal protein sources. Fourteen percent killed specifically for trade, whereas $29 \%$ hunted primarily for recreation, but appreciated the benefits of either meat or money. Eighty percent of respondents in Uttaranchal were prepared to stop hunting if meat was supplied to them free of cost. However, in Himachal Pradesh $41 \%$ did not wish to give up hunting under any circumstances.

In terms of their body weight, Galliformes formed $10.4 \%$ of the total wildmeat consumed by respondents in Himachal Pradesh. This was much lower (4\%) in Uttaranchal. The majority of the wildmeat that was consumed was derived from mammals, i.e. Himalayan tahr in Himachal Pradesh and wild boar in Uttaranchal (Table 3).

There was no significant difference in the extraction rates of common animals between the two forest management systems in Uttaranchal (Table 4).
Table 3 Amount of meat consumed by respondents in Himachal Pradesh and Uttaranchal. Values are means for each household that hunts.

\begin{tabular}{lcc}
\hline & \multicolumn{2}{l}{ Consumption $(\mathrm{kg})$} \\
\cline { 2 - 3 } Species & Himachal & Uttaranchal \\
\hline Galliformes & & \\
Black francolin & 0.0 & 0.4 \\
Cheer pheasant & 5.0 & 0.3 \\
Chukar partridge & 4.8 & 0.7 \\
Common hill-partridge & 0.0 & 0.1 \\
Himalayan monal & 3.4 & 0.0 \\
Kalij pheasant & 0.0 & 8.6 \\
Koklass pheasant & 8.0 & 0.6 \\
Snowcock & 0.3 & 0.0 \\
Western tragopan & 1.9 & 0.0 \\
Mammals & & \\
Barking deer & 13.6 & 10.6 \\
Goral & 47.9 & 19.6 \\
Himalayan black bear & 0.0 & 0.0 \\
Himalayan brown bear & 0.0 & 0.0 \\
Himalayan tahr & 108.9 & 0.0 \\
Indian porcupine & 0.0 & 5.1 \\
Indian wildboar & 0.0 & 179.4 \\
Leopard & 0.0 & 0.0 \\
Musk deer & 6.7 & 9.0 \\
Total & 224 & 267.4 \\
\hline
\end{tabular}

\section{Discussion}

A large range of mammals and Galliformes are hunted in the western Himalaya and many of these are of conservation concern (BirdLife International, 2000; Fuller et al., 2000; Fuller \& Garson, 2000; IUCN, 2003). In the villages surveyed the hunted species include four that are categorized as Vulnerable and two as Lower Risk/ near-threatened on the IUCN Red List (IUCN, 2003). The Vulnerable species are cheer pheasant, western tragopan, Himalayan black bear and Himalayan tahr, whilst the near-threatened species are goral and musk deer (Table 1). We did not record hunting of the serow (although it was only found around two of the villages we surveyed), yet its inclusion on the Red List is because its decline is believed to be due to overharvesting (IUCN, 2003).

Assessment of the impact that the hunting level we report may have on wild populations is difficult. For example, the Vulnerable western tragopan was recorded as hunted in more than $80 \%$ of the villages around which it occurred and the mean number of individuals killed per hunting household was one. This species is widely regarded as difficult to detect reliably in the wild and there are probably few significant populations left anywhere in its range (Fuller \& Garson, 2000). Together these may imply that the species occurs at low densities and its forest habitat is becoming increasingly fragmented. If this is the case then the level of hunting may well make a 
Table 4 Extraction rates (number of animals hunted per hunting family per year) in state- and community-managed forests in Uttaranchal, with Mann-Whitney test for differences between forest types.

\begin{tabular}{|c|c|c|c|c|c|c|c|c|}
\hline \multirow[b]{2}{*}{ Species } & \multicolumn{3}{|c|}{ State-managed forests } & \multicolumn{3}{|c|}{ Community-managed forests } & \multicolumn{2}{|c|}{ Mann-Whitney } \\
\hline & $\mathrm{N}$ & Mean & SE & $\mathrm{N}$ & Mean & SE & Z & $\mathrm{P}$ \\
\hline \multicolumn{9}{|l|}{ Galliformes } \\
\hline Black francolin & 26 & 1.27 & 0.54 & 6 & 1.33 & 0.61 & -1.05 & $>0.05$ \\
\hline Chukar partridge & 22 & 1.54 & 0.74 & 4 & 0.0 & 0.0 & -0.91 & $>0.05$ \\
\hline Koklass pheasant & 27 & 0.55 & 0.27 & 4 & 0.51 & 0.5 & -0.21 & $>0.05$ \\
\hline White-crested kalij & 27 & 9.55 & 1.39 & 6 & 6.5 & 1.25 & -0.85 & $>0.05$ \\
\hline \multicolumn{9}{|l|}{ Mammals } \\
\hline Barking deer & 27 & 0.52 & 0.21 & 6 & 0.33 & 0.32 & -0.33 & $>0.05$ \\
\hline Goral & 27 & 0.7 & 0.24 & 6 & 0.67 & 0.49 & -0.21 & $>0.05$ \\
\hline Indian porcupine & 26 & 0.42 & 0.21 & 6 & 0.0 & 0.0 & -1.0 & $>0.05$ \\
\hline
\end{tabular}

substantial difference to increasingly small and accessible populations. On the other hand, the species could simply be difficult to detect and its encounter rate may not reflect its natural abundance. In this case, removal of the relatively low number of individuals reported here may have little impact.

An added difficulty in assessing whether or not hunting is a conservation problem in the western Himalaya is its illegality. Hunting of wildlife in India is against the law and most rural communities in the areas that we surveyed are aware of this. Therefore, the respondents might have underreported the number of animals that they killed.

Despite these complications we believe that several issues are clear, and suggest that hunting does demand urgent attention. Firstly, western Himalayan forest is much reduced in area and the blocks that remain are increasingly fragmented (Anon., 2000). This means that populations of species endemic to this habitat type are at risk, not only from loss of habitat and populations becoming isolated from each other, but also from improved access for hunters. Winter is likely to be a critical season as snow forces many species to lower altitudes, where they come into close contact with villagers. Therefore, the loss of relatively small numbers of individuals may have a disproportionate impact on small and isolated populations.

Secondly, the species that are most widely hunted are also those that are of conservation concern. This six most widely hunted species (as indicated by the number of villages where they are hunted as a percentage of villages around which they occur) are Himalayan tahr, western tragopan, musk deer, Himalayan monal, cheer pheasant, and goral. All of these, apart from Himalayan monal, are categorized as either Vulnerable or Lower Risk:nearthreatened on the Red List. In contrast, only the Himalayan black bear and serow are of global conservation concern amongst the remaining 17 species.

Thirdly, these species that are of global conservation concern are more widely distributed in Himacha Pradesh than in Uttaranchal and are therefore more widely hunted in the former. In Uttaranchal, in contrast, the species that are widely hunted are not considered to be at risk of extinction. For example, the kalij pheasant occurs in a variety of habitats throughout the study area and along the Himalaya front ranges (Ali \& Ripley, 1983) and occurs in various habitats throughout its broad geographical distribution (Johnsgard, 1986; McGowan, 1994).

Where hunting is a conservation issue for these species, there is a need not only for an understanding of its impact on wild populations of the hunted species, but also an understanding of why certain species are hunted. This is because the combined economic value of wildmeat from subsistence use and legal and illegal commercial trade contributes significantly to many local and national economies (Lamarque, 1995; Rao \& McGowan, 2002). There does not appear to be a large commercial market in wildmeat in the area that we studied, and only selected species are hunted to meet local needs. For example, no carnivores are hunted for their meat.

The body size of the animal also appears to be important, and large-bodied species such as Himalayan tahr, wild boar or goral provide more meat per cartridge (or quantity of gunpowder) used. Another factor that influences which species are killed in the western Himalaya is the species available. People living in the outer ranges of the Himalaya do not have direct access to high altitude areas and thus do not regularly hunt high altitude species. For example, the low altitude kalij was heavily hunted in Uttaranchal but not in Himachal Pradesh. This was because most respondents from Himachal Pradesh had access to high altitude areas and hunted other species in those areas.

The apparent similarity in the extraction patterns of animals between the two forest management regimes in Uttaranchal suggests that stronger intervention is required if there is a need to reduce hunting levels. As the species involved are not considered threatened and tend to be widespread, however, it is not clear whether offtake 
is adversely affecting wild populations. This requires investigation.

\section{Acknowledgements}

Our thanks are due to the Forest Departments of Himachal Pradesh and Uttaranchal for their assistance. We also thank Drs Ghazala Shabuddin and John Carroll for useful comments on the manuscript. The Oriental Bird Club funded this study. Data were also collected during the Himalayan quail survey funded by the World Pheasant Association.

\section{References}

Ali, S. \& Ripley, S.D. (1987) A Handbook of Birds of India and Pakistan. Oxford University Press, New Delhi, India.

Alvard, M., Robinson, J.G., Redford, K.H. \& Kaplan, H. (1997)

The sustainability of subsistence hunting in the Neotropics. Conservation Biology, 11, 977-982.

Anon. (1999) State of the Forests in India. Forest Survey of India Ministry of Environment \& Forests, Government of India, New Delhi, India.

Anon. (2000) Population and Forests: A Report on India. UNDP, New Delhi, India.

Bakarr, M.I., da Fonseca, G.A.B., Mittermeier, R., Rylands, A.B. \& Paenemilla, K.W. (2001) Hunting and bushmeat utilization in the African rainforest: prospective towards a blueprint for conservation action. Advances in Applied Biodiversity Science 2. Conservation International, Washington, DC, USA.

BirdLife International (2000) Threatened Birds of the World. BirdLife International, Cambridge, UK.

BirdLife International (2004) State of the World's Birds: Indicators for Our Changing World. BirdLife International, Cambridge, UK.

Bodmer, R.E., Eisenberg, J. \& Redford, K. (1997) Hunting and likelihood of extinction of Amazonian mammals. Conservation Biology, 11, 460-466.

Diamond, J. \& Case, T.J. (1986) Overview, introductions, extinctions, exterminations and invasions. In Community Ecology (eds J. Diamond \& T.J. Case), pp. 56-79. Harper and Row, New York, USA.

Fuller, R.A., Carroll, J.P., \& McGowan, P.J.K. (eds) (2000) Partridges, Quails, Francolins, Guineafowl and Turkeys: Status Survey and Conservation Action Plan 2000-2004. IUCN, Gland, Switzerland and Cambridge, UK and World Pheasant Association, Reading, UK.

Fuller, R.A. \& Garson, P.J. (eds) (2000) Pheasants: Status Survey and Conservation Action Plan 2000-2004. IUCN, Gland, Switzerland and Cambridge, UK and World Pheasant Association, Reading, UK.

Hilton-Taylor, C. (compiler) (2000) 2000 IUCN Red List of Threatened Species. IUCN, Gland, Switzerland and Cambridge, U.K.

ICBP (1992) Putting Biodiversity on the Map: Priority Areas for Global Conservation. International Council for Bird Preservation, Cambridge, UK.

IUCN (2003) 2003 IUCN Red List of Threatened Species. IUCN, Gland, Switzerland [http:/ / www.redlist.org, accessed 13 May 2004]

Johnsgard, P.A. (1986) Pheasants of the World. Oxford University Press, Oxford, UK.
Lamarque, F.A. (1995) The French Co-operation's strategy in the field of African wildlife. In Integrating People and Wildlife for a Sustainable Future (eds J.A. Bissonette \& P.R. Krausman), pp. 267-270. Wildlife Society, Bethesda, USA.

McGowan, P.J.K. (1994) Family Phasianidae (pheasants and partridges). In Handbook of the Birds of the World. Volume 2 (eds J. del Hoyo, A. Elliott \& J. Sargatal), pp. 434-552. Lynx Edicions, Barcelona, Spain.

Olson, D.M. \& Dinerstein, E. (1998) The Global 200: a representation approach to conserving the earth's most biologically valuable ecoregions. Conservation Biology, 12, 502-515.

Peres, C.A. \& Terborgh, J. (1995) Amazonian nature reserves: an analysis of defensibility, status of existing conservation units and design criteria for the future. Conservation Biology, 9, 34-46.

Prater, S.H. (1971) The Book of Indian Animals. Oxford University Press, New Delhi, India.

Rao, M. \& McGowan, P.J.K. (2002) Wild-meat use, food security, livelihoods and conservation: issues in international conservation. Conservation Biology, 16, 580-583.

Reid, W.V. (1992) How many species will there be? In Tropical Deforestation and Species Extinction (eds T.C. Whitmore \& J.A. Sayer), pp. 55-73. Chapman and Hall, London, UK.

Robinson, J.G. \& Bennett, E.L. (eds) (2000) Hunting for Sustainability in Tropical Forests. Columbia University Press, New York, USA.

Rodgers, W.A. \& Panwar, H.S. (1988) Planning A Protected Area Network in India. Unpublished Report. Wildlife Institute of India, DehraDun, India.

Sethi, P. \& Hilaluddin (2001) Structuring financial empowerment for localized development with Joint Forest Management (JFM): examples from Madhya Pradesh, India. Sustainable Development, 9, 87-102.

Stattersfield, A.J., Crosby, M.J., Long, A.J. \& Wege, D.C. (1998) Endemic Bird Areas of The World: Priority Areas for Conservation. BirdLife International, Cambridge, UK.

Wilkie, D.S. \& Carpenter, J.F. (1999) Bushmeat hunting in Congo Basin: an assessment of impacts and options for mitigation. Biodiversity and Conservation, 8, 927-955.

\section{Biographical sketches}

Rahul Kaul has studied Himalayan Galliformes since the 1980s when he conducted fieldwork on the ecology of cheer peasant. Since then he has carried out surveys and research designed to establish the status of India's threatened pheasant species at various sites across the Himalayas.

Hilaluddin has been studying the sustainability of forest based biomass extractions in India, particularly in the Joint Forest Management areas. He is now interested in looking at the role of wildmeat in the economy of local communities.

J.S. Jandrotia is an instructor in the District Institute of Education and Training, Himachal Pradesh, and has carried out wildlife surveys in remote areas of the State. He is a member of the Pheasant Specialist Group.

Philip J.K. McGowan has carried out fieldwork on Galliformes in India, China, Malaysia, Brunei and the Philippines since the early 1980s. He co-authored the compilation of three IUCN/WPA Action Plans that were published in 1995 and has been the Conservation Director of WPA since 2001. 